\title{
Divine Temporality and Providential Bodgery
}

\author{
R. T. MULLINS \\ University of Helsinki \\ rtmullins@gmail.com
}

\begin{abstract}
In contemporary debates, one is presented with temporal and timeless conceptions of divine eternality. Each conception is said to have various consequences for understanding divine perfection and providence. In this paper, I shall consider a pair of arguments against divine temporality that suggest that a temporal God could potentially make mistakes, thus making the temporal God less than perfect. I shall develop these objections, and discuss various ways for the temporalist to reply.
\end{abstract}

Keywords: Time and Eternity, Providence, Open Theism, Molinism, Determinism

Within contemporary philosophical theology, one has an array of models of God to consider. ${ }^{1}$ Most models of God affirm that God is a necessarily existent person with essential properties like maximal power, maximal knowledge, maximal goodness, and freedom. Most models of God also affirm that God has contingent properties like creator and sustainer of the universe. Different models of God wish to affirm other, contested, essential divine properties like love, impassibility, omnisubjectivity, simplicity, and so on. For the purposes of this paper, I shall narrow my focus to one contested essential divine property: eternality. Very few models of God will deny that God has the property of eternality, but opinions differ over how to interpret this property. Eternality can be interpreted either as timelessness or temporality. I shall ask us to consider two models of God. One model of God affirms a timeless eternality, and the other affirms a temporal eternality. The main question to consider is which God is the greatest possible being. I shall examine two connected arguments from T.J. Mawson that seek to show that a timeless God is greater than a temporal God. My aim is to clarify Mawson's arguments, and articulate different replies that are open to the divine temporalist.

In section 1 of this paper, I shall articulate the two rival models of God. In section 2, I identify ways of testing models of God for greatness. In section 3, I shall articulate Mawson's arguments for thinking that a timeless God is greater

${ }^{1}$ Diller and Kasher (2013). 


\section{R. T. MULLINS}

than a temporal God. In section 4, I shall discuss five ways that the future can be open or closed. This will provide the conceptual machinery that is needed to develop Mawson's arguments, and identify the different possible temporalist responses. In section 5, I discuss four possible replies that a temporalist can offer in response to Mawson's arguments. Each reply attempts to show that timeless eternality does not make God greater. Each reply has its costs, but these costs have nothing to do with whether or not God is timeless. Thus, each reply provides some reason for thinking that Mawson's arguments against temporality have been undermined. In section 6, I offer some concluding remarks.

\section{A Tale of Two Deities}

For the purposes of this paper, I will consider two rival models of God: a timeless God and a temporal God. I shall start by stating what these models of God have in common before discussing their differences. As I shall understand it, both models of God are committed to the philosophical tradition of perfect being theology. ${ }^{2}$ Perfect being theology is a philosophical method for determining which properties God has essentially. Perfect being theology is only designed to inform a person of God's essential properties. It is not a method designed to inform a person about God's contingent or accidental properties, like being the creator of the universe. In order to establish God's contingent properties, one will have to consider arguments from natural and revealed theology. ${ }^{3}$ For the purposes of this paper, I shall grant that each model of God has a way to establish that God is the creator and sustainer of the universe. However, my main interest in this paper is perfect being theology.

Perfect being theology starts by defining God as perfect, or the greatest metaphysically possible being. It offers an analysis of what it means to be the greatest possible being, and then provides a few simple steps for discerning which essential properties the greatest possible being has. ${ }^{4}$ The first question for a perfect being theologian to ask is this. What does it mean for God to be the greatest metaphysically possible being? In order to answer this question, I need to introduce three concepts: great-making properties, extensive superiority, and intensive superiority.

I shall begin with great-making properties. Yujin Nagasawa says that some property $p$ is a great-making property if, all else being equal, it contributes to the intrinsic greatness of its possessor. ${ }^{5}$ Often times, philosophers and theologians state this as any property that it is intrinsically better to have than not have. A

\footnotetext{
2 E.g. Rogers and Hasker (2011).

${ }^{3}$ Morris $(1991,28-35)$.

4 Speaks $(2018,8-18)$.

${ }^{5}$ Nagasawa $(2017,53-55)$.
} 
great-making property is an intrinsic property that would improve the greatness of any being that has it, and it would not worsen the greatness of any being that possesses it. ${ }^{6}$ Perfect being theologians emphasize that great-making properties cannot entail any liabilities or imperfections.

When it comes to discerning which properties God has essentially, the perfect being theologian will say that God has whatever properties are intrinsically better to have than not have. Part of the method of perfect being theology is to identify these great-making properties, and predicate them of God. A common list of great-making properties includes existence, personhood, power, knowledge, goodness, and freedom. However, there is more at play in the method of perfect being theology.

Merely identifying a list of potential great-making properties is not enough to establish that God is the greatest metaphysically possible being. To be the greatest metaphysically possible being is to have extensive superiority and intensive superiority to all other possible beings.

A being $x$ is extensively superior to some being $y$ if and only if $x$ has all of the same great-making properties as $y$, and $x$ has some great-making properties that $y$ does not have. ${ }^{7}$ In the case of God, perfect being theologians say that God has all of the compossible great-making properties, and is thus extensively superior to all other possible beings.

Extensive superiority focuses on the possession of multiple great-making properties, whereas intensive superiority focuses on the intensity of individual great-making properties. Nagasawa says that some being $x$ is intensively superior to some being $y$ if and only if $x$ has some great-making property that $y$ has, but to a greater degree of intensity than $y .{ }^{8}$ In the case of God, perfect being theologians claim that God has all of His degreed great-making properties to the maximal degree of intensity. I say "degreed properties" because some greatmaking properties do not obviously come in degrees of intensity. For instance, properties like existence and eternality are traditionally taken to be great-making properties, but they do not obviously have degrees of intensity in which they can be possessed.

Both models of God that I wish to consider agree on the previous account of divine perfection. Further, they agree that God is a necessarily existent person with maximal power, maximal knowledge, maximal goodness, and freedom.

What other great-making properties do they agree on? Each model affirms that God is an eternal being. A being is eternal if and only if it does not begin to exist and does not cease to exist. If God exists of necessity, then God is an eternal

\footnotetext{
${ }^{6}$ Nagasawa $(2017,65)$.

7 Nagasawa $(2017,56)$.

${ }^{8}$ Nagasawa $(2017,57)$.
} 


\section{R. T. MULLINS}

being. ${ }^{9}$ This is because a necessarily existent being cannot begin to exist, nor fail to exist. Each model affirms that God exists of necessity, thus each model affirms that God is an eternal being. However, Mawson points out that each model disagrees over how to interpret divine eternality. This is because eternality can be understood in two different ways: timeless or temporal. ${ }^{10}$

To say that God is timeless is to say that God necessarily exists without beginning, without end, and without succession. To say that God is temporal is to say that God necessarily exists without beginning and without end. However, the divine temporalist will deny that God necessarily exists without succession. The temporalist will say that God must undergo succession as God freely exercises His power. The exercise of divine power entails a change from not acting to acting. Which interpretation of eternality is the great-making property - timeless eternality or temporal eternality? It will be difficult to answer that question without first addressing how one goes about discerning which model is the greatest.

\section{How to Test for Greatness?}

How does one discern on which model God is the greatest? In this section, I shall identify two sets of strategies for answering this question. The main thing that these strategies have in common is the demand to satisfy the definition of God as the greatest metaphysically possible being. These different strategies aim to show that a rival model of God cannot satisfy this definition of God.

How does one argue this? There are two broad ways that one can argue this. First, one can try to show that a model of God cannot satisfy the metaphysically possible aspect of the definition of God. Call these Metaphysically Impossible Strategies because they aim to show that a rival model of God is metaphysically impossible. This can be done by showing that a model of God is internally incoherent, or by showing that it is not consistent with some fact about the world. ${ }^{11}$ For example, one might argue that a particular model of God's conception of omnipotence is incoherent because it cannot handle the paradox of the stone. Alternatively, one might argue that a particular model of God's understanding of divine freedom and simplicity are not compossible because simplicity entails that God cannot be free. Or perhaps one argues that a particular model of God is inconsistent with the existence of evil in our world. Such examples are fairly standard in contemporary philosophy of religion.

The next strategies that I shall discuss focus on the greatest aspect of the definition of God. Call these Not the Greatest Strategies because they aim to show

\footnotetext{
${ }^{9}$ Clarke (1998, Section V).

${ }^{10}$ Mawson $(2018,3)$.

11 Nagasawa (2013).
} 
that a rival model of God cannot be the greatest metaphysically possible being. This can be done by showing that a rival model of God is extensively inferior because it lacks one or more great-making properties. Perhaps one argues that omnisubjectivity is a great-making property, and that any model of God that lacks omnisubjectivity is extensively inferior to any model of God that includes this property. Alternatively, one can show that a rival model of God is intensively inferior because it does not have one or more great-making properties to the greatest possible degree of intensity.

In what follows, I will consider a version of the Not the Greatest Strategy against divine temporality. This argument is trying to show that the temporal God is intensively inferior to the timeless God with regards to knowledge, power, and goodness. ${ }^{12}$

\section{Is the Timeless God Intensively Superior?}

In Mawson's recent book, The Divine Attributes, he offers a version of the Not the Greatest Strategy that warrants a careful consideration. Mawson grants that both divine timelessness and divine temporality provide coherent models of God. ${ }^{13}$ Mawson also grants that both models of God are extensively equal. However, Mawson argues that divine temporality makes God less great than is metaphysically possible. As Mawson understands it, a temporal God cannot infallibly know the future free choices of creatures. Without this foreknowledge, Mawson argues that the temporal God could potentially make mistakes that would render Him less powerful and less good than a timeless God who has infallible foreknowledge. Thus, the timeless God is intensively superior with regards to knowledge, power, and goodness. That is three strikes against divine temporality!

I shall start with Mawson's definitions of omniscience, omnipotence, and perfect goodness. Mawson's definition of omniscience is fairly standard. God is essentially omniscient in that for all true propositions, God infallibly knows that they are true, and for all false propositions, God infallibly knows that they are false. ${ }^{14}$

Mawson defines omnipotence as the most power-granting set of abilities that is logically possible. ${ }^{15}$ As Mawson explains, the maximal power-granting set does not simply contain all abilities. This is because not all abilities are powers. Some abilities are liabilities. ${ }^{16}$ For example, the ability to perform irrational

\footnotetext{
12 Mawson $(2018,11)$.

13 Mawson $(2018,29)$.

14 Mawson $(2018,34-5)$.

15 Mawson $(2018,41)$.

${ }^{16}$ Mawson $(2018,42)$.
} 


\section{R. T. MULLINS}

actions is a liability. ${ }^{17}$ Thus, this ability will not be included in the maximal power-granting set of abilities.

Mawson defines perfect goodness as involving three objective moral dimensions: deontological, consequentialist, and virtue. ${ }^{18}$ According to Mawson, a perfectly good person always does what He has most objective reason to do. As omniscient, God will always know what He has most objective reason to do. As omnipotent, God will be free to perform the action that He has most objective reason to do. ${ }^{19}$ Further, a perfectly good God is one who's intentions are always good, and who never fails to satisfy His obligations. A perfectly good God's actions will give rise to the best possible consequences. In performing these good actions, God will instantiate virtuous character traits such as generosity, wisdom, and so forth. ${ }^{20}$

With these definitions, I can now examine Mawson's argument that divine temporality entails having less than maximal knowledge, power, and goodness. I'll state these as two different arguments: the knowledge argument and the divine bodgery argument.

\subsection{The Knowledge Argument}

The details of Mawson's argument are admittedly sparse. What I present here is what I think Mawson is attempting to argue. As far as I can tell, Mawson's knowledge argument can be stated as follows.

K1) A being who infallibly knows the future free actions of creatures knows more than a being who does not infallibly know the future free actions of creatures.

K2) A timeless God can infallibly know the future free actions of creatures.

K3) A temporal God cannot infallibly know the future free actions of creatures.

K4) Thus, a timeless God infallibly knows more than a temporal God.

(K1) seems fairly uncontroversial, so I do not think it needs justification. (K4) follows straightforwardly from (K1) through (K3). All of the action seems to be taking place in (K2) and (K3). If Mawson can justify (K2) and (K3), he can claim a point in favour of divine timelessness. The timeless God knows the future free actions of creatures whereas the temporal God does not. Thus, the timeless God

\footnotetext{
17 Mawson $(2018,217)$.

18 Mawson $(2018,47)$.

${ }^{19}$ Mawson $(2018,50)$.

${ }^{20}$ Mawson $(2018,47)$.
} 
has intensive superiority with regards to knowledge. How does Mawson justify these premises?

The details in Mawson's account are sparse. To start, Mawson asserts that temporalists affirm presentism, and atemporalists affirm eternalism. This is a useful pedagogical device for Mawson's book, but as Mawson himself would concede, there are other options. On presentism, only the present moment of time exists. On eternalism, all moments of time exist in before and after relations. ${ }^{21}$ As Mawson sees it, the timeless God is able to see all of time at once in a timeless moment. Thus, giving the timeless God infallible knowledge of the future, hence the acceptance of (K2). The version of divine temporality that Mawson focuses on is called open theism. Open theists deny that God knows the future, thus accepting (K3).

Mawson alludes to further justification for (K2). He argues that if a temporal God knows the future with infallible omniscience, then creatures cannot be free. ${ }^{22}$ As Mawson understands freedom, a person is free only if she is the source of her action, and has the ability to do otherwise. ${ }^{23}$ If God knows that you will perform action $A$ tomorrow, then you cannot fail to perform action A. Thus, you will not have the ability to do otherwise.

However, Mawson does not make it clear why this is a unique problem for divine temporality, nor does he explain exactly how timelessness helps. ${ }^{24}$ As is well known, the freedom/foreknowledge problem can be easily reformulated to fit God's timeless knowledge. ${ }^{25}$

As it stands, it is not entirely clear how to justify (K2) and (K3). In section 4, I shall develop some of the conceptual machinery that is needed to clarify Mawson's argument. Then, in section 5, I shall use this conceptual machinery to explore several temporalist options for replying to Mawson's argument.

\footnotetext{
${ }^{21}$ I shall limit myself to presentist and eternalist ontologies of time. There are other ontologies of time, but space does not permit a discussion of views such as the growing block, the moving spotlight, branching time, hypertime, and fragmentalism.

${ }^{22}$ Mawson $(2018,36)$.

${ }^{23}$ Mawson's comments on free will in Mawson (2018) are quite limited. For a full discussion of his view on free will see Mawson (2011).

${ }^{24} \mathrm{I}$ am guessing that Mawson is affirming a view called the simple foreknowledge view. For a recent detailed defence of this view, see K. A. Rogers (2019). However, I say that Mawson ought not to affirm the simple foreknowledge view because it is providentially useless, and thus undermines his divine bodgery argument against divine temporality. Cf. Hasker (2009).

${ }^{25}$ Vicens and Kittle (2019, 23-24), Helm (2001, 187). However, Florio and Frigerio (2019) offer a recent defence of timelessness and foreknowledge by employing an ontology of time called fragmentalism. Discussing this ontology of time is beyond the scope of this paper.
} 


\subsection{The Divine Bodgery Argument}

Mawson's divine bodgery argument has more details than his knowledge argument. However, it seems to rest on the success of the knowledge argument. The divine bodgery argument has to do with God's knowledge of the future, and God's ability to providentially bring about what God wants. Mawson argues that a God without exhaustive foreknowledge could make mistakes, and really bodge things up. One bodges an action when (i) one performs an action with the intention of bringing about certain results, and (ii) those results do not come about. $^{26}$

According to Mawson, a God who bodges things up is not as powerful as a God who could not possibly bodge things up. The advantage is meant to go to divine timelessness because of the alleged increase in knowledge that timelessness is meant to give. Again, according to Mawson, divine timelessness affirms eternalism. Thus, God knows what happens in the future, and thus apparently cannot bodge things up. According to Mawson, things are different for the divine temporalist. Recall that Mawson assumes the temporalist is going to be an open theist who denies that God knows the future. If a temporalist denies that God infallibly knows the future, then God cannot be certain what the outcome will be for His actions. Thus, it is possible that the temporal God bodge things up because He does not know for certain that His actions will bring about their intended effects.

According to Mawson, this not only makes the temporal God less powerful, it also makes the temporal God less good. A God who bodges things up is not as good as a God who could not possibly bodge things up. Recall that Mawson says that a perfectly good God is good in 3 ways: virtue, deontology, and consequences. The issue of bodging is not obviously an attack on the temporal God's goodness along virtue or deontological lines. The problem of divine bodging is about God's consequential goodness because the temporal God cannot ensure that His actions will bring about their intended effects.

According to Mawson, the timeless God eternally decrees and knows all that He decrees and knows. God's particular intentions that certain things take place at specific times is included in God's eternal decree. ${ }^{27}$ This, according to Mawson, is not something that a temporal God can consistently do. Again, this is because Mawson assumes that the best temporalist position is open theism. Again, on open theism, God cannot know which future events will in fact occur. Thus, God cannot eternally decree His own particular intentional actions. This opens up the possibility for divine bodging.

\footnotetext{
${ }^{26}$ Mawson $(2018,41)$.

${ }^{27}$ Mawson $(2018,32)$.
} 
Perhaps Mawson's divine bodgery argument can be stated like this.

B1) A being who cannot bodge things up is more powerful and good than a being who can bodge things up.

B2) If God does not infallibly know the future, then God can bodge things up.

B3) If God does infallibly know the future, then God cannot bodge things up.

B4) A timeless God infallibly knows the future.

B5) Thus, a timeless God cannot bodge things up.

B6) A temporal God cannot infallibly know the future.

B7) Thus, a temporal God can bodge things up.

B8) Thus, the timeless God is more powerful and good than the temporal God.

\subsection{Initial Reactions to Mawson's Arguments}

In what follows, I wish to briefly explore several options for responding to Mawson's arguments. In so doing, I shall demonstrate that divine timelessness is not doing any work to establish that God has more knowledge, power, and goodness. Thus, nothing about timelessness obviously makes God intensively superior to a temporal God. To be sure, each option for responding to the arguments comes with a cost, but as I shall point out, the costs have nothing to with whether God is timeless or temporal.

In the next section, I shall lay out some of the conceptual machinery needed to develop the options that are open to the temporalist. Then I shall discuss three ways that a temporalist might reject premise (K3) of Mawson's knowledge argument, and (B6) of the divine bodgery argument. I will also explore one way for the temporalist to reject premise (K2) of the knowledge argument, and (B2) of the divine bodgery argument.

\section{The Five Fold Openness of the Future}

In a series of articles, Alan Rhoda has articulated five different senses in which the future may be considered as open or closed: ontically, causally, alethically, epistemically, and providentially. ${ }^{28}$

I will start with the future being ontically open. According to Rhoda, "The future is ontically open as of time $t$ if and only if no unique, complete sequence

${ }^{28}$ Rhoda (2011, 2013). 


\section{R. T. MULLINS}

of events which are future relative to $t$ exists simpliciter." 29 There are at least two ontologies of time that have an ontically open future. These are presentism and the growing block. An eternalist ontology would have an ontically closed or settled future in that there exists a unique set of events that are future relative to some time $t$.

If the future is ontically open, one might wonder about the truth-values of propositions about the future. This leads to the next issue-alethic openness. ${ }^{30}$ Do propositions about the future have a determinate truth-value of true or false? If the future is alethically open, the answer is no. If the future is alethically closed or settled, the answer is yes.

How does one get an alethically settled future if the future is ontically open? There are several options. There might simply exist true propositions about the future. Or prior conditions might determine the truth-values of future-tensed propositions. If these prior conditions determine the truth-values of futuretensed propositions, then the future is not causally open. According to Rhoda, "The future is causally open if and only if there is more than one causally possible future." 31

As I shall discuss below, theological determinists affirm that the future is causally closed, or settled, in that God has causally determined how the entire timeline shall unfold. If God causally determines the entire future, then it is easy to see how God could know how the entire future will unfold. Other theologians will deny that God causally determines how the entire future will unfold, but will still maintain that God knows the truth-values of the future-tensed propositions. Hence, both of these groups of theologians agree that the future is epistemically closed because it is known which possible future will in fact come to pass. As an open theist, Rhoda is committed to the future being epistemically open in that no one, not even God, knows exactly how the future will unfold. ${ }^{32}$

If the future is epistemically settled for God, then one can say that the future is providentially settled because God knows that He has acted in a way that guarantees that a unique causally possible future will come to pass. This is often stated as God ordaining or decreeing that a particular timeline shall occur. According to Rhoda, the future is providentially open if and only if God has not ordained or decreed how the entire future will unfold. ${ }^{33}$

Theists like Mawson affirm that the future is settled or closed in all five ways, whereas open theists like Rhoda will affirm that the future is open in all five ways. However, there are other options.

\footnotetext{
${ }^{29}$ Rhoda (2013, 293).

${ }^{30}$ Rhoda $(2013,293)$.

${ }^{31}$ Rhoda $(2013,289)$.

32 Rhoda $(2013,290)$.

33 Rhoda $(2013,291)$.
} 


\section{Temporalist Responses to Mawson's Arguments}

With these 5 different understandings of how the future is open or closed, I can articulate different ways for the temporalist to respond to Mawson's argument. In each case, I will show that Mawson's argument fails to show that divine timelessness provides God with more knowledge or providential control. I begin with the earliest view of omniscience in the Western tradition, and then proceed to consider views that develop later in history.

\subsection{Option 1: The Traditional Story of Omniscience}

There is one question that Mawson does not explicitly address that is crucial for any debate about omniscience. This is called the Source Question. ${ }^{34}$ How does God know the truth-values of all propositions? There are several ways that one might answer it. Here is one way to answer this question.

Divine Self-Knowledge: God has a perfect introspective knowledge of Himself, and thus knows all things. God's knowledge is in no way dependent upon what happens in time.

This view goes back at least to Aristotle, though Aristotle says that God's knowledge is only of necessary truths. For Aristotle, God is completely unaware of any contingent truths, like what is happening in the universe or what will happen in the future. ${ }^{35}$ Early Christian thinkers attempted to build knowledge of contingent truths into God's self-knowledge. This view can be found in thinkers like the early Augustine before he developed his doctrine of predestination. ${ }^{36} \mathrm{On}$ this view, it seems like God just gets the knowledge for free. Something about God's essence just entails that there are truth-values for all propositions, and that God automatically knows these propositions. For example, God's essence just entails the truth of the proposition <Sally sits on Arthur's Seat at 12 April, 2025>. If an atemporalist like Augustine can affirm this view, I see no reason why a temporalist cannot affirm this view. The temporalist can say that God has a perfect introspective knowledge of Himself, and thus knows all things. Whether or not God is timeless or temporal is really irrelevant. A temporal God can have a perfect introspective knowledge of Himself. If that is all it takes to know the

${ }^{34}$ Anfray (2014, 335).

35 Florio and Frigerio $(2019,71)$.

36 Augustine, The Trinity XV.13.22. Charnock (1864, 464ff). Though it should be said that Stephen Charnock elsewhere affirms that God's knowledge causes all things $(1864,386)$. The claim that God's knowledge causes all things is fairly common within the classical tradition. Cf. Rogers (2019). 


\section{R. T. MULLINS}

future, then a temporal God can know the future. Timelessness is not doing any work here to increase God's knowledge. All the work is being done by God's self-knowledge. Thus, the temporalist can reject premise (K3) of Mawson's knowledge argument. Again, that premise says that the temporal God cannot infallibly know the future free actions of creatures.

One might push back and say that the temporal God cannot know this without undermining creaturely freedom. Yet, notice that nothing about God existing with or without succession changes the truth-value of the proposition $<$ Sally sits on Arthur's Seat at 12 April, 2025>. On the self-knowledge version of omniscience, God's essence just somehow entails the truth of this proposition. It is the essence of God that alethically settles the future. It is through God's selfknowledge of His own essence that the future is epistemically settled.

If anything is a problem for creaturely freedom, it will not be God's knowledge, but rather His essence. God's timelessness is not doing anything here to resolve any tensions between freedom and foreknowledge. It doesn't matter if God's knowledge of this proposition is timeless or temporal because the truthvalue remains the same, and the truth-value is determined by God's essence. Thus, if one adopts the self-knowledge version of omniscience, one will not be able to spot any obvious advantage for timelessness over temporality with regards to knowledge of what creatures will freely do in the future.

What about divine goodness and power? Say the divine temporalist accepts the self-knowledge account of omniscience. She can reject premise (B6) of the divine bodgery argument which says that the temporal God does not infallibly know the future. Thus, avoiding the conclusion that the temporal God is capable of bodging up history, and thus avoiding the conclusion that the temporal God has less power and goodness than the timeless God.

However, certain questions arise at this point. How does this self-knowledge work? God's self-knowledge seems to be related to the doctrine of the divine ideas. ${ }^{37}$ The doctrine of divine ideas starts by pointing out that God is the source of all of the great-making properties. As the source of the great-making properties, creatures can only instantiate properties like power or knowledge by participating in God's power and knowledge. The doctrine of the divine ideas states that through a perfect self-knowledge of His own divine essence, God knows all of the ways that created beings could participate in His essence.

As interesting as the divine ideas doctrine is, there is pushback against this view, even from within the tradition of divine timelessness. Within the classical Christian tradition, theologians began to notice that God's self-knowledge only gives God knowledge of all necessarily true propositions, and propositions about

\footnotetext{
37 Levering (2017, 29ff).
} 
what is possible..$^{38}$ The problem that these theologians wished to address is how God is able to know which contingent propositions are true. For example, how does God know that one particular future will occur instead of a different future?

This is a question that a proponent of timelessness and temporality will both need to address. If the self-knowledge view does not give God knowledge that one particular future will occur, this is a problem for everyone who wishes to affirm God's knowledge of the future.

\subsection{Option 2: Theological Determinism}

How does God know the future? One major line of thought in the classical tradition offered an answer to this question by appealing to God's act, will, or decree. On this view, God knows the future because God has a perfect knowledge of the cause of the future-i.e. His act or decree to create a universe with a specific timeline. Theologians who affirm this solution say that God knows which future timeline will occur because God knows that He has causally determined which particular timeline will occur. Call this view theological determinism.

According to Derk Pereboom, "Theological determinism is the position that God is the sufficient active cause of everything in creation, whether directly or by way of secondary causes such as human agents." ${ }^{39}$ Theological determinists say that God is the primary cause of everything, whereas created things are secondary causes. To say that God directly brings about something is to say that God causes a particular state of affairs to obtain without any secondary causes. God indirectly brings something about by causing creatures to causally bring about a particular state of affairs. ${ }^{40}$ Theological determinists typically, though not always, affirm compatibilism which says that human freedom is compatible with divine determinism.

There are several ways to tell the theological determinist story. ${ }^{41}$ I will argue that in each case, divine timelessness is doing no work in contributing to God's knowledge nor providential governing of the universe. As such, a timeless God is not intensively superior to the temporal God.

Earlier I noted the 5 fold way that the future is open or closed. A theological determinist has some wiggle room here with how to develop her theological system, but she does have several commitments. All versions of theological determinism are committed to the future being alethically, providentially, epistemically, and causally settled. ${ }^{42}$ This is because theological determinism says

\footnotetext{
${ }^{38}$ Goris (2005, 111), Molina (1988, 130-144).

39 Pereboom $(2016,112)$.

${ }^{40}$ Webster (2009, 164 and 167), Helseth (2011, 31).

${ }^{41}$ Cf. Couenhoven (2018).

42 Rhoda $(2013,295)$.
} 


\section{R. T. MULLINS}

that God cannot know the future unless He determines the truth-values of propositions about the future. ${ }^{43}$

Theological Determinist Story: Prior to the act of creation, God knows all the possible universes and exhaustive timelines that He could create via His natural knowledge. God's act of creation, or decree to create, refers to God determining that a particular universe and timeline come to exist. In selecting to create a universe and timeline, God exhaustively determines the truth-values of the propositions about that universe and timeline, thus the future is alethically settled. This decree to create also providentially and causally settles the future. Subsequent to God's decree, God knows the truth-values of the propositions about that universe and timeline via His free knowledge. Thus, the future is also epistemically settled.

This story needs a bit of unpacking because this theological determinist story can be told on both divine timelessness and divine temporality. To start, I take a universe to be a particular collection of contingent, spatio-temporally related objects. I understand a timeline to be a particular ordering of a series of temporal moments. A temporal moment of time is a way things are but could be subsequently otherwise.

The theological determinist often distinguishes between God's natural knowledge and God's free knowledge. She says that God's natural knowledge gives God knowledge of all possible universes and exhaustive timelines that He could create. This knowledge is prior to God's free knowledge, which is knowledge of which timeline God has freely determined to bring about. On this view, until God freely decides to create a particular universe with a particular timeline, there simply is no fact of the matter as to which possible timeline will become actual. ${ }^{44}$ In other words, the future is alethically, epistemically, providentially, ontically, and causally open until God decrees that a particular future be actualized. Subsequent to God's decree to create a particular timeline, God knows what will occur because He knows which timeline He has freely determined to bring about. The decree is the foundation of God's free knowledge. ${ }^{45}$

All of this talk about "prior" and "subsequent" sounds deeply temporal. However, the "prior" in the story could be a "logically prior" in the case of divine timelessness, or it could be a "temporally prior" in the case of divine temporality. The advocate of divine timelessness, Paul Helm, explains that the classical tradition developed the notion of "logical moments" in the timeless life of God in order to solve various theological puzzles. These logical moments function like

\footnotetext{
43 Shedd $(1888,394)$. Cf. Pereboom $(2016,114)$.

${ }^{44}$ Feinberg $(2001,313)$.

45 Berkhof $(1984,102)$.
} 
temporal moments in that they stand in some kind of order of priority and posteriority to one another. Theological determinists who affirm timelessness are split over exactly how many logical moments there are in the timeless life of God. ${ }^{46}$ However, they agree that these logical moments are not temporal, so there is no temporal succession in the life of the timeless God. ${ }^{47}$

I have my doubts about the coherency of these logical moments, but I can grant their coherency for the sake of argument. If logical moments are coherent, then the proponent of divine timelessness can give a reading of the theological determinist story that is consistent with her view. But the divine temporalist can also give a reading of the theological determinist story that is consistent with her view in terms of temporal moments. Thus, there is no obvious advantage to be gained by affirming divine timelessness.

There is a way to nuance the theological determinist story in order to further drive home the point that divine timelessness is not doing any work. The theological determinist story can be told on different conceptions of the ontic openness of the future. Mawson's argument assumes that a proponent of divine temporality will affirm a presentist ontology of time, but the temporalist need not affirm presentism. A theological determinist who affirms divine temporality can believe in presentism. She will say that the future is alethically, providentially, epistemically, and causally settled, but that the future is ontically open. However, a temporalist can easily affirm eternalism. ${ }^{48}$ If she affirms eternalism, she will say that the future is ontically, alethically, providentially, epistemically, and causally settled. This five-fold settledness of the future looks exactly like Mawson's account of the timeless God's relationship to the world. Hence, it should be clear that timelessness is not doing any work since a temporalist can also affirm the five-fold settledness of the future.

Since the theological determinist story can be told on divine temporality, the divine temporalist has an easy way out of Mawson's knowledge argument. She can reject premise (K3) in Mawson's knowledge argument. Again, premise (K3) states that if God is temporal, then God cannot know the future free actions of creatures. The theological determinist says that "free" in premise (K3) should be understood according to compatibilism. She affirms that the temporal God knows what His creatures will freely do in the future.

Mawson will push back at this point. He rejects theological determinism because he thinks that it offers an unattractive view of human freedom, yet concedes that it is an option for a theist to affirm. ${ }^{49}$ So long as it is an option, the

${ }^{46}$ Berkhof $(1984,118-121)$.

${ }^{47}$ Helm $(2015,57)$.

${ }^{48}$ For a temporalist view that affirms not only eternalism but also hypertime, see Hudson (2014).

${ }^{49}$ Mawson $(2016,142)$. 


\section{R. T. MULLINS}

temporalist can accept determinism in order to avoid Mawson's knowledge argument. Moreover, one will recall that Mawson defines freedom as having it within one's power to do other than what one in fact does. ${ }^{50}$ Theological determinists are typically quite happy to affirm that a human person could have acted differently, but that it is certain that they will act as God has decreed. ${ }^{51}$ Whether or not the theological determinist can consistently affirm this view is a topic for another day. Also, it is unclear if Mawson can consistently maintain that free creatures have the ability to do otherwise since he affirms that the future is closed in all five ways. ${ }^{52}$ For the purposes of this paper, I maintain that theological determinism is one option for avoiding Mawson's knowledge argument.

The temporalist who affirms theological determinism can also avoid the conclusion of Mawson's divine bodgery argument. The theological determinist rejects premise (B6), which says that a temporal God cannot infallibly know the future. A theological determinist says that God does know the future because He determined it. Hence, she can easily affirm that it is impossible for God to bodge things up. Thus, there is no loss to God's knowledge, power, and goodness to be had by denying divine timelessness.

\subsection{Option 3: Molinism}

Not every theologian is happy with theological determinism. If one accepts libertarian freedom, she will be rejecting the determinist's compatibilist understanding of freedom. Theologians who affirm libertarian freedom tend to affirm one of two views on providence: either Molinism or open theism. Both Molinism and open theism will say that God has a perfect knowledge of Himself, and thus knows all that is necessarily true, and all that is possible. In other words, both are happy to accept God's natural knowledge.

Molinists and open theists are also happy to say that God has a perfect knowledge of whatever God determines to bring about. However, both will say that God does not determine everything. From here, disagreement arises between Molinists and open theists.

Molinists claim that God has something called middle knowledge. The Molinist says that middle knowledge is distinct from God's natural and free knowledge. The content of God's middle knowledge is said to be God's prevolitional knowledge of conditional future contingent propositions about what creatures would freely do in any possible circumstance that they might be

${ }^{5}$ Mawson $(2018,36)$.

${ }^{51}$ Berkhof (1984, 107), Erickson (2004, 383-384), Florio and Frigerio $(2019,95)$. For a detailed historical analysis of this position, see Muller (2017).

52 For an argument that eternalism is inconsistent with libertarian freedom, see Koperski (2015, 112-117). 
placed in. The Molinist says that God is not the cause of creaturely actions. In other words, God does not determine the truth-values of these particular propositions about what creatures would do, thus allegedly avoiding divine determinism. God's middle knowledge is said to be subsequent to His natural knowledge, but prior to His free knowledge. Molinists claim that God uses this knowledge to narrow down the range of feasible timelines that He knows via His natural knowledge. God then selects a possible timeline from the set of feasible timelines. Subsequent to God's free choice of a timeline, God knows what He has freely decreed to bring about. ${ }^{53}$

Molinist Story: Prior to the act of creation, God knows all the possible universes and exhaustive timelines that He could create via His natural knowledge. Subsequently, God knows via His middle knowledge what creatures would freely do in any possible circumstance. Subsequently, God's act of creation, or decree to create, refers to God willing that a particular universe and timeline come to exist. In selecting to create a universe and timeline, God determines the truth-values of the propositions about which universe and timeline will be actual. Subsequently, God has free knowledge of which universe and timeline that He has willed to create. Thus the future is alethically, epistemically, and providentially settled.

As with the determinist story, the Molinist story can be told on divine timelessness and divine temporality. The proponent of divine timelessness will refer to all of these moments as logical moments. ${ }^{54} \mathrm{~A}$ proponent of divine temporality can refer to these as temporal moments. Alternatively, she could refer to some of them as logical moments, and others as temporal moments.

As with theological determinism, one can nuance the Molinist story by adding in a temporal ontology. Yet, the results are not quite so obvious to me. A Molinist, like William Lane Craig, will affirm a presentist ontology of time along with divine temporality. ${ }^{5}$ Someone like Craig will affirm that the future is alethically, epistemically, and providentially settled, yet causally and ontically open. It is conceivable that a temporalist and Molinist affirm an eternalist ontology of time, yet it is unclear to me what advantages this view has. ${ }^{56}$ On this view, the future

${ }^{53}$ Flint $(1998,42-43)$.

${ }^{54}$ Flint $(1998,64)$.

${ }^{55}$ Craig (2001a, 2001b).

${ }^{56}$ For a discussion of this option, see Florio and Frigerio (2019, chapter 5). They also maintain that this view might be combined with a branching structure of time in order to allow for the future to be causally open even though it is ontically closed. Personally, I find myself uncertain 


\section{R. T. MULLINS}

would be alethically, epistemically, providentially, causally, and ontically settled. My worry is that this combination of views is indistinguishable from theological determinism because it agrees to the five-fold settledness of the future. To be sure, the Molinist will say that creatures are offering their own causal contributions to history, but the determinist says the same thing. I'll leave this particular problem aside because exploring it would derail the conversation. Instead, I will assume a Molinist view like Craig's is the best option for the temporalist.

Since the Molinist story can be told on timelessness or temporality, there is no advantage for divine timelessness here with respect to God's knowledge. Thus, the divine temporalist can affirm Molinism, and reject premise (K3) of Mawson's knowledge argument. She also rejects premise (B6) of the divine bodgery argument. Hence, a temporalist who is a Molinist can say that there is no loss to God's knowledge, power, and goodness by rejecting divine timelessness.

Will someone like Mawson find Molinism to be a satisfactory option for avoiding his argument? In a footnote, Mawson rules out Molinism as an option for divine knowledge and providence, but he doesn't say why. ${ }^{57}$ However, it is easy to guess Mawson's reason because there are serious objections to Molinism. However, that debate is ongoing, so the temporalist can arguably affirm Molinism in order to avoid Mawson's objections to divine temporality. ${ }^{58}$

\subsection{Option 4: Open Theism}

Not every theist is happy with Molinism. The open theist and theological determinist both argue that middle knowledge is incoherent or impossible. Both also agree that it is impossible for God to foreknow what creatures with libertarian freedom will in fact do in the future. ${ }^{59}$ The open theist parts ways with the determinist here. The theological determinist denies libertarian freedom for creatures by affirming that God causally determines the future. The open theist denies that God causally determines the future free actions of creatures, and affirms libertarian freedom. As stated before, the open theist is committed to the five-fold openness of the future with regards to the actions of creatures. There are other aspects of the future that might be determined, such as divine prophecies or naturally reoccurring events like the rising of the sun, and God is

\footnotetext{
about how the future can be ontically closed without being causally closed, but I concede that I have not produced any argument against this possibility.

${ }^{57}$ Mawson $(2018,36)$.

${ }^{58}$ Cf. Perszyk (2012).

${ }^{59}$ Berkhof (1984, 107), Zimmerman (2010, 791), Inwagen (2008).
} 
thus able to know those. ${ }^{60}$ But by and large, much of the future is open with regards to creaturely freedom.

Given the five-fold openness of the future, the open theist rejects premise (K2) of Mawson's knowledge argument. Since the future is ontically, providentially, causally, and alethically open, the future is also epistemically open because there simply is nothing more to know about the future other than those small portions of the future that the open theist says are already determined. In other words, given the openness of the future, it is metaphysically impossible for there to be more for God to know. Even a timeless God could not infallibly know the future in exhaustive detail because there is nothing for God to know. Thus, the open theist maintains that her model of God is not intensively inferior to the timeless God with regards to knowledge.

Mawson has anticipated this sort of reply. This is why he offers his divine bodgery argument to establish that the open theist God is less powerful and good than a timeless God. The open theist, however, has a story to tell that she thinks avoids God having less power and goodness than is metaphysically possible.

Open Theist Story: Prior to the act of creation, God knows all the possible universes and exhaustive timelines that He could create via His natural knowledge. Given God's commitment to creating a universe that contains beings with libertarian freedom, it is impossible to know what those creatures will in fact freely do in the future. Hence, there is no exhaustive timeline for these universes. Yet, God knows all of the possible actions that His creatures might perform in any possible circumstance within the universe. Prior to the act of creation, God develops an exhaustive contingency plan for every possible future free action in order to guarantee that He achieves His ultimate goal for creation. ${ }^{61}$ Subsequently, God's act of creation, or decree to create, refers to God willing that a particular universe come to exist. It does not refer to God willing that a particular timeline should come about. Instead, God's decree to create contains a stated goal for the future history of the universe that God intends to providentially bring about in cooperation with His free creatures.

Theological determinists find the open theist story to be in conflict with divine sovereignty, and thus reject libertarian freedom. But open theists claim that their view is not in conflict with divine sovereignty. This reveals a different strategy with regards to Mawson's divine bodgery argument. The theological determinist

${ }^{60}$ Rice $(2020,47)$.

${ }^{61}$ Here I am closely following the providential model of open theism developed by Boyd (2011). As I note below, not every open theist is happy with the language of "guarantee." 


\section{R. T. MULLINS}

and the Molinist reject premise (B6), which says that the temporal God does not know the future. The open theist, however, accepts premise (B6) given her commitment to the five-fold openness of the future. Thus, the open theist needs to reject a different premise in the divine bodgery argument.

The open theist has several different premises that she can reject. For example, an open theist like William Hasker will reject (B3) and (B4) as too simplistic. (B3) says that if God knows the future, then God cannot bodge things up. (B4) says that a timeless God knows the future. Hasker says that merely timelessly knowing the future does not give God any providential control. ${ }^{62}$ For example, God could merely timelessly know that He is going to bodge things up. In order to get providential control, Hasker says that timelessness will need to be supplemented by either theological determinism or Molinism. ${ }^{63}$ I have already argued that theological determinism and Molinism can be affirmed by divine temporalists. Thus, timelessness is not doing any work here to prevent divine bodgery.

Furthermore, given the open theist's commitment to the five-fold openness of the future, she will reject (B4), which is the claim that the timeless God knows the future. The open theist says that it is impossible for God to know the future regardless of whether God is timeless or temporal. Since the divine bodgery argument hinges on God's knowledge of the future, the open theist might say the bodgery argument is a non-starter. Alternatively, she might say that if divine bodgery is a problem, it is a problem for everyone given the five-fold openness of the future.

Ultimately, however, the open theist ought to insist that divine bodgery is not a problem. She ought to reject (B2), which says that if God does not know the future, then God can bodge things up. How can the open theist do this?

To start, recall the definition of bodging. One bodges an action when (i) one performs an action with the intention of bringing about certain results, and (ii) those results do not come about. Does the God of open theism bodge? To be fair to Mawson, open theists seem to admit that something like divine bodgery could take place. ${ }^{64}$ Sometimes open theists play up just how risky it is for God to create a universe. For example, John Sanders classic book on open theism is called The God Who Risks. ${ }^{65}$ It might seem pretty obvious that a God who risks could possibly bodge things up. However, the possibility of divine bodgery depends on what God's intentions are for creation and the possibility of God not getting that result. As Sanders points out, if God does not get everything He wants from the universe, then that is because God intended to create the sort of universe where

\footnotetext{
62 Hakser (2009).

${ }^{63}$ Hasker (2011, 283-284).

${ }^{64}$ Hakser $(2017,60)$.

65 Sanders (2007).
} 
He cannot guarantee that He will get everything that He desires. ${ }^{66}$ An open theist like Sanders can say that this is not a straightforward bodge because God intended to create a universe with free creatures where the future is uncertain, and that is exactly what God ended up with. The fact that God intended for this result, and did in fact achieve this result, demonstrates that there is no divine bodgery.

Perhaps Mawson could push back. Mawson could grant that, with regards to God's act of creation, there is no bodgery. The God of open theism intended to create a universe with free creatures and an uncertain future. The God of open theism can clearly perform that action without bodging. Yet, Mawson can point out that open theists don't think that God's only goal for creation is to create a universe with free creatures and an uncertain future. Open theists typically have more built into God's goal for creation. For example, open theists like Gregory Boyd typically say that a major reason God creates a universe with free creatures and an uncertain future is so that God can create a universe where genuine divine-human love is not only possible, but will eventually become actual. ${ }^{67} \mathrm{~A}$ major divine goal in creating the universe is for God to actually enter into genuine loving relationships with as many creatures as possible. Call this Major Divine Goal.

MDG: One of God's major goals for creation is to enter into genuine loving relationships with as many creatures as possible.

Someone like Mawson could argue that it is possible for God to bodge up MDG. Mawson can say that God intends to establish loving relationships with His creatures, and that God fails to achieve these relationships in at least some cases. Thus, bodging things up. ${ }^{68}$

How can the open theist respond? Open theists typically distinguish between meticulous providence and general providence. ${ }^{69}$ Open theists insist that they affirm general providence, whereas theological determinists and Molinists affirm a meticulous providence. On meticulous providence, God has an exhaustive control over each specific situation. Whatever God intends to bring about for each specific situation will certainly be achieved. God adopts specific-benefit policies for governing the world which would state that every divine act at each moment should achieve a very particular benefit. For example, every instance of evil should be for the purpose of building souls. ${ }^{70}$

\footnotetext{
${ }^{66}$ Sanders $(2007,243)$.

${ }^{67}$ Boyd $(2011,190)$.

${ }^{68}$ Mawson $(2018,47)$.

${ }^{69}$ Sanders $(2007,224-225)$.

${ }^{70}$ Hasker $(2017,61)$.
} 


\section{R. T. MULLINS}

Things are allegedly different on a general providence where God sets up the general structures of the universe in order to allow free creatures to have meaningful input in how history unfolds. On general providence, God adopts general-policies for governing the world. God does not have a specific intention for each and every event that takes place in the universe. ${ }^{71}$ For example, in order to make it possible for creatures to enter into loving relationships with God, God has to create and sustain a fine-tuned universe with law-like regularities. In many instances of evil that occur in the world, the open theist says that God could unilaterally intervene to prevent the evil. Yet, the open theist says that in most cases God will not intervene because God is employing a general-policy to maintain the law-like regularities. God's general policy of maintaining these law-like regularities promotes the MDG because it continues to make possible creaturely freedom.

It might seem that the open theist's general providence is a promising way to avoid divine bodgery. This is because God allegedly does not have specific results that He intends to achieve for each individual action that He performs other than the general-policies He has adopted in order to achieve the MDG. To see this, recall that the open theist can point out that MDG does not entail a specific result like universal salvation. MDG only says that one of God's major goals is to enter into genuine loving relationships with as many creatures as possible, which could fall short of universalism. Universalism is a contentious issue among open theists, and space does not permit me to enter into that debate. ${ }^{72}$ What I can say is that the open theist can claim that God set out to achieve a general goal of entering into loving relationships with as many creatures as possible, and He adopts general-policies to help Him achieve that goal. The open theist can say that if God had a more specific goal in mind, like universal salvation or the salvation of exactly 144,000 people, then it might be that God could bodge things up. But in God's unsurpassable wisdom, God selected the more general goal of MDG, which avoids any threat of divine bodgery.

Yet divine bodgery might be avoided in another way that the average open theist will not expect. On the strongest versions of open theism, God has His overarching goal for creation, and He has an exhaustive contingency plan set in motion in order to achieve the MDG. The analogy sometimes given by open theists is that God is like a master chess player who knows that He will win the game prior to starting the game. God knows all the possible moves that His creatures could make, and He has an exhaustive plan put in place in order to win. God does not know in fact how the game will unfold, but He knows for certain

\footnotetext{
${ }^{71}$ Sanders $(2007,226)$.

72 Thomas Talbot affirms universalism whereas John Sanders denies it. See their essays in Parry and Partridge (2003).
} 
that He will win before He begins playing. ${ }^{73}$ What an open theist like this can say is that prior to the act of creating the universe, God intends to achieve the MDG by means of His exhaustive contingency plan, and He knows for certain that He will achieve His goal on the basis of His exhaustive contingency plan. For example, Boyd maintains that God's contingency plan involves eliminating possible timelines where the MDG fails. ${ }^{74}$ Hence, when God performs His act of creating the universe, He intends to bring about a particular goal, and He knows for certain that the results will eventually come about. He just doesn't know exactly how the results will come about. That doesn't look like divine bodgery in any objectionable way, though Mawson will demur. ${ }^{75}$ In fact, God's plan has built into it the elimination of potential bodgery from the start.

For Boyd, the contingency plans are built into God's original intention, and those contingency plans eliminate potential divine bodgery before God creates the universe. Recall that one bodges an action when (i) one performs an action with the intention of bringing about certain results, and (ii) those results do not come about. Boyd can say that no divine bodge has taken place since God intends to rely on His contingency plans, and He does in fact rely on His contingency plans as a result.

Of course, someone might wonder how God's contingency plan can eliminate bodgery from the start and still be considered a theory of general providence. Recall that open theists claim that they affirm a general providence whereas theological determinists and Molinists affirm a meticulous providence. This assertion, however, has been called into question in recent literature, with various philosophers arguing that Molinists can affirm a general providence, and that open theists can affirm a meticulous providence. ${ }^{76}$ For example, Greg Welty has recently argued that the open theist's general providence looks remarkably like meticulous providence. ${ }^{77}$ This is because each divine action is ultimately geared towards furthering His overarching goal for creation. Each individual divine act is intended to further God's goal. Since (i) God knows all of the possible

${ }^{73}$ Geach (1977) and Boyd (2011). However, other open theists call into question if God can actually guarantee that His purposes be achieved. Yet, these open theists will still maintain that the risk of divine failure is so improbable as to be negligible. For discussion of this, see Grossl and Vicens (2014).

${ }^{74}$ Boyd (2011, 207).

${ }^{75}$ Mawson can grant that divine contingency plans can help mitigate against divine bodgery. Yet Mawson thinks the open theist's contingency plans can only minimize the potential risk of divine bodgery, or they can help God put things right after a bodge has taken place. For example, one might see the story of Noah as involving God putting things right after a bodge has taken place (Mawson 2018, 46-47). This is different from Boyd's understanding of contingency plans as discussed above.

${ }^{76}$ Judisch (2012).

77 Welty (2019, 146). 


\section{R. T. MULLINS}

outcomes of His individual acts, (ii) all of the probabilities of each act furthering His goals, and (iii) has an exhaustive contingency plan for each course of action, thus God will always be able to select a course of action that furthers His ultimate goal for creation. What this means is that the God of open theism is constantly selecting actions that furthers His goals, which looks remarkably meticulous.

To be sure, many prominent open theists will not like having a meticulous account of providence. ${ }^{78}$ In my view, the divine temporalist should not be put off by having a meticulous open theist account of providence. Instead, she should welcome this result because it offers another clear way to reject premise (B2) of Mawson's argument.

\section{Conclusion}

According to Keith Ward, divine timelessness gives the illusion of power over the future. Ward maintains that omnipotence is the only thing needed for God to have power over the future..$^{79}$ In his estimation, timelessness is not doing any work in this regard. I believe that I have offered several reasons to support this conclusion as it pertains to Mawson's knowledge argument and bodgery argument. I have articulated several ways for a divine temporalist to respond to Mawson's arguments, and have attempted to show that timelessness does not give God any advantage in terms of power, goodness, or knowledge. Each view that I have discussed does come with various costs, but I maintain that those costs do not effect the debate over whether or not God is timeless or temporal. More work does need to be done on comparing rival models of God, and I hope that I have helped set the stage for this work to continue.

\section{Bibliography}

Anfray, Jean-Pascal. 2014. "Molina and John Duns Scotus." In A Companion to Louis de Molina, edited by Matthais Kaufmann and Alexander Aichele. Leiden: Brill. https://doi.org/10.1163/9789004262188 011.

Augustine, Saint. 1958. City of God. Translated by Gerald G. Walsh, Demetrius B. Zema, Grace Monahan and Daniel J. Honan. New York: Double Day.

Augustine, Saint. 1991. The Trinity. Translated by Edmund Hill. Hyde Park: New City Press.

Berkhof, Louis. 1984. Systematic Theology. Edinburgh: The Banner of Truth Trust. Boyd, Gregory A. 2011. "God Limits His Control." In Four Views on Divine Providence, edited by Dennis W. Jowers. Grand Rapids: Zondervan.

\footnotetext{
${ }^{78}$ E.g. Rice (2020).

${ }^{79}$ Ward $(1982,162)$.
} 
Boyd, Gregory A. 2000. God of the Possible: A Biblical Introduction to the Open View of God. Grand Rapids: Baker Books.

Charnock, Stephen. 1864. The Complete Works of Stephen Charnock. Edited by James M'Cosh. Vol. 1. Edinburgh: James Nichol.

Clarke, Samuel. 1998. A Demonstration of the Being and Attributes of God and Other Writings. Cambridge: Cambridge University Press. https://doi.org/10.1017/CBO9780511583346.

Couenhoven, Jesse. 2018. Predestination: A Guide for the Perplexed. London: T\&T Clarke.

Craig, William Lane. 2001a. God, Time, and Eternity: The Coherence of Theism II: Eternity. London: Kluwer Academic Publishers. https://doi.org/10.1007/97894-017-1715-1.

Craig, William Lane. 2001b. "The Middle Knowledge View." In Divine Foreknowledge: Four Views, edited by James K. Beilby and Paul R. Eddy. Downers Grove: InterVarsity Press.

Deng, Natalja. 2018. God and Time. Cambridge: Cambridge University Press.

Diller, Jeanine, and Asa Kasher, . 2013. Models of God and Alternative Ultimate Realities. New York: Springer. https://doi.org/10.1007/978-94-007-5219-1.

Erickson, Millard J. 2004. Christian Theology. 2nd. Grand Rapids: Baker Books.

Feinberg, John. 2001. No One Like Him: The Doctrine of God. Wheaton: Crossway Books.

Flint, Thomas P. 1998. Divine Providence: The Molinist Account. Ithaca: Cornell University Press.

Florio, Ciro De, and Aldo Frigerio. 2019. Divine Omniscience and Human Free Will: A Logical and Metaphysical Analysis. Cham: Palgrave Macmillan.

Geach, P.T. 1977. Providence and Evil. Cambridge : Cambridge University Press.

Goris, Harm. 2005. “Divine Foreknowledge, Providence, Predestination, and Human Freedom." In The Theology of Thomas Aquinas, edited by Rik Van Nieuwenhove and Joseph Wawrykow. Notre Dame: University of Notre Dame Press.

Grossl, Johanness, and Leigh Vicens. 2014. "Closing the Door on Limited-Risk Open Theism." Faith and Philosophy 31: 475-485. https://doi.org/10.5840/faithphil201412923.

Hasker, William. 2011. "An Open Theist Theodicy of Natural Evil." In Molinism: The Contemporary Debate, edited by Ken Perszyk. Oxford: Oxford University Press. https://doi.org/10.1093/acprof:oso/9780199590629.003.0018.

Hasker, William. 2017. "An Open Theist View." In God and the Problem of Evil: Five Views, edited by Chad Meister and James K. Dew. Downers Grove: IVP Academic. 
Hasker, William. 2009. "Why Simple Foreknowledge is Still Useless (In Spite of David Hunt and Alex Pruss)." Journal of the Evangelical Theological Society 52: 537-544.

Hasker, William, and John Sanders. 2017. "Open Theism Progress and Prospects." Theologische Literaturzeitung 9: 859-872.

Helm, Paul. 2010. Eternal God: A Study of God Without Time. Second. Oxford: Oxford University Press.

https://doi.org/10.1093/acprof:oso/9780199590391.001.0001.

Helm, Paul. 2015. "How Are We to Think of God's Freedom." European Journal for Philosophy of Religion 7: 49-65. https://doi.org/10.24204/ejpr.v7i3.104.

Helm, Paul. 2001. “The Augustinian-Calvinist View." In Divine Foreknowledge: Four Views, edited by James K. Beilby and Paul R. Eddy. Downers Grove: InterVarsity Press.

Helseth, Paul Kjoss. 2011. "God Causes All Things." In Four Views on Divine Providence, edited by Dennis W. Jowers. Grand Rapids: Zondervan.

Hick, John. 2007. Evil and the God of Love. London: Palgrave Macmillan.

Hudson, Hud. 2014. The Fall and Hypertime. Oxford: Oxford University Press. https://doi.org/10.1093/acprof:oso/9780198712695.001.0001.

Inwagen, Peter van. 2008. "What Does an Omniscient Being Know About the Future?" In Oxford Studies in Philosophy of Religion, edited by Jonathan L. Kvanvig. Oxford: Oxford University Press.

Judisch, Neal. 2012. Meticulous Providence and Gratuitous Evil. Vol. 4, in Oxford Studies in Philosophy of Religion, edited by Jonathan Kvanvig. Oxford: Oxford University Press. https://doi.org/10.1093/acprof:oso/9780199656417.003.0004.

Koperski, Jeffrey. 2015. The Physics of Theism: God, Physics, and the Philosophy of Science. Malden: Wiley Blackwell. https://doi.org/10.1002/9781118933800.

Kronen, John, and Eric Reitan. 2011. God's Final Victory: A Comparative Philosophical Case for Universalism. New York: The Continuum International Publishing Group Inc.

Leftow, Brian. 2011. "Why Perfect Being Theology?" International Journal for Philosophy of Religion 103-118. https://doi.org/10.1007/s11153-010-9267-0.

Levering, Matthew. 2017. Engaging the Doctrine of Creation: Cosmos, Creatures, and the Wise and Good Creator. Grand Rapids: Baker Academic.

Lombard, Peter. 2007. The Sentences Book 1: The Mystery of the Trinity. Translated by Giulio Silano. Ontario: Pontifical Institute of Mediaeval Studies.

Mawson, T. J. 2016. “Classical Theism has No Implications for the Debate between Libertarianism and Compatibilism." In Free Will and Theism: Connections, Contingencies, and Concerns, edited by Kevin Timpe and Daniel Speak. Oxford: Oxford University Press.

https://doi.org/10.1093/acprof:oso/9780198743958.003.0009. 
Mawson, T. J. 2011. Free Will: A Guide for the Perplexed. London: The Continuum International Publishing Group.

Mawson, T. J. 2002. "Omnipotence and Necessary Moral Perfection are Compatibile: A Reply to Morriston." Religious Studies 38: 215-223. https://doi.org/10.1017/S0034412502006017.

Mawson, T. J. 2018. The Divine Attributes. Cambridge: Cambridge University Press.

Molina, Luis De. 1988. On Divine Foreknowledge: Part IV of the Concordia. Translated by Alfred J. Freddoso. Ithaca: Cornell University.

Morris, Thomas V. 1991. Our Idea of God: An Introduction to Philosophical Theology. Downers Grove: InterVarsity Press.

Muller, Richard A. 2017. Divine Will and Human Choice: Freedom, Contingency, and Necessity in Early Modern Reformed Thought. Grand Rapids: Baker Academic.

Nagasawa, Yujin. 2017. Maximal God: A New Defense of Perfect Being Theism. Oxford: Oxford University Press. https://doi.org/10.1093/oso/9780198758686.003.0004.

Nagasawa, Yujin. 2013. "Models of Anselmian Theism." Faith and Philosophy 30: 3-25. https://doi.org/10.5840/faithphil20133011.

Parry, Robin A., and Christopher H. Partridge, . 2003. Universal Salvation? The Current Debate. Grand Rapids: William B. Eerdmans Publishing Company.

Pereboom, Derk. 2016. "Libertarianism and Theological Determinism." In Free WIll and Theism: Connections, Contingencies, and Concerns, edited by Kevin Timpe and Daniel Speak. Oxford: Oxford University Press. https://doi.org/10.1093/acprof:oso/9780198743958.003.0007.

Perszyk, Ken, ed. 2012. Molinism: The Contemporary Debate. Oxford: Oxford University Press. https://doi.org/10.1093/acprof:oso/9780199590629.001.0001.

Rhoda, Alan R. 2013. “Open Theism and Other Models of Divine Providence." In Models of God and Alternative Ultimate Realities, edited by Jeanine Diller and Asa Kasher. New York: Springer. https://doi.org/10.1007/978-94-007-5219-1 24.

Rhoda, Alan R. 2011. "The Fivefold Openness of the Future." In God in an Open Universe: Science, Metaphysics, and Open Theism, edited by William Hasker, Thomas Jay Oord and Dean Zimmerman. Eugene: Pickwick Publications.

Rice, Richard. 2020. The Future of Open Theism: From Antecedents to Opportunities . Downers Grove: IVP Academic.

Rogers, Katherin A. 2019. "Foreknowledge, Freedom, and Vicious Circles: Anselm vs Open Theism." In Philosophical Essays Against Open Theism, edited by Benjamin H. Arbour. London: Routledge. https://doi.org/10.4324/9781315755700-7.

Rogers, Katherin, and William Hasker. 2011. "Anselm and the Classical Idea of God: A Debate." In Philosophy of Religion: The Key Thinkers, edited by Jeffrey J. Jordan. London: Continuum International Publishing Group. 
Sanders, John. 2007. The God Who Risks: A Theology of Divine Providence. Downers Grove: IVP Academic.

Shedd, W.G.T. 1888. Dogmatic Theology. Vol. 1. New York: Charles Scribner's Sons.

Speaks, Jeff. 2018. The Greatest Possible Being. Oxford: Oxford University Press. https://doi.org/10.1093/oso/9780198826811.001.0001.

Vicens, Leigh, and Simon Kittle. 2019. God and Human Freedom. Cambridge : Cambridge University Press. https://doi.org/10.1017/9781108558396.

Ward, Keith. 1982. Rational Theology and the Creativity of God. Oxford: Basil Blackwell Publisher.

Webster, John. 2009. “On the Theology of Providence." In The Providence of God, edited by Francesca Aran Murphy and Philip G. Ziegler. London: T\&T Clark.

Welty, Greg. 2019. “Open Theism, Risk-Taking, and the Problem of Evil." In Philosophical Essays Against Open Theism, edited by Benjamin H. Arbour. London: Routledge. https://doi.org/10.4324/9781315755700-10.

Zimmerman, Dean. 2010. "The A-Theory of Time, Presentism, and Open Theism." In Science and Religion in Dialogue, edited by Melville Y. Stewart. Malden: Blackwell Publishing Ltd.

Published Online: October 09, 2020 